\title{
Hemopigmented Villonodular Synovitis of Hand
}

\author{
M. N. Dabire, R. Ait Moha, M. Fahsi, M. Chahed, A. El Baitil, A. R. Haddoun, M. Fadili, M. Nechad \\ Depatment of Orthopedy and Traumatology (A4), CHU Ibn Rochd, Casablanca, Morroco \\ Email: dabnar1@yahoo.fr
}

How to cite this paper: Dabire, M.N., Ait Moha, R., Fahsi, M., Chahed, M., El Baitil, A., Haddoun, A.R., Fadili, M. and Nechad, M. (2016) Hemopigmented Villonodular Synovitis of Hand. Open Access Library Journal, 3: e3040.

http://dx.doi.org/10.4236/oalib.1103040

Received: September 24, 2016

Accepted: October 21, 2016

Published: October 25, 2016

Copyright $\odot 2016$ by authors and Open Access Library Inc.

This work is licensed under the Creative Commons Attribution International License (CC BY 4.0).

http://creativecommons.org/licenses/by/4.0/

(c) (i) Open Access

\begin{abstract}
The location of giant cells tumor in synovial sheaths of fingers tendons is often frequent. We bring a case. An 18-years-old patient without particular medical history, since two years, had a bilobate tumefaction of right index's proximal interphalangeal, painless, firm, movably under the skin, without inflammatory sign. Standard radiography showed cortical thickening. A complete excision is performed. Pathological results revealed tenosynovial giant cells tumor without malignancy. Giant cells tumor of tendon sheaths represent the second soft parts of the hand after arthro-synovial cyst. The prognosis depends on invasion of digital noble structures.
\end{abstract}

\section{Subject Areas \\ Orthopedics}

\section{Keywords}

Giant Cells Tumor, Fingers Tendons, Synovial Sheaths

\section{Introduction}

The location of giant cells tumors in synovial sheaths of fingers tendons is often frequent. It is the localized form of hemopigmented villonodular synovitis and the second soft tissue tumor of the hand after the arthrosynovial cyst [1]. We report an observation of a case.

\section{Observation}

It is an 18-years-old Sir K.M, student in second year of bachelor, right-handed, without particular medical history.

The patient presented, since two years, a bilobate tumefaction on dorsum of proximal interphalangeal of the index, firm, movable relative to the two planes, without inflammatory signs (Figure 1). The joint is free. 
The standard radiography has showed a thickening of the with respect to the tumor (Figure 2).

As treatment, it was performed a total resection biopsy through posterior approach of well limited tumor, in shirt button, passing under the extensor tendon without being adhered but acceding to the posterior face of the join without being invaded, buff, multinodular (Figure 3).

The pathological result has revealed a tenosynovial giant cells tumor without malignancy.

The evolution up to 4 months is good.

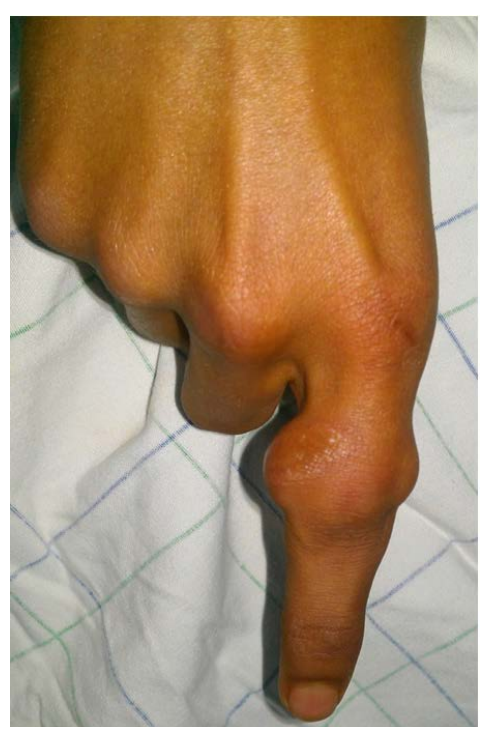

Figure 1. Preoperative tumor.
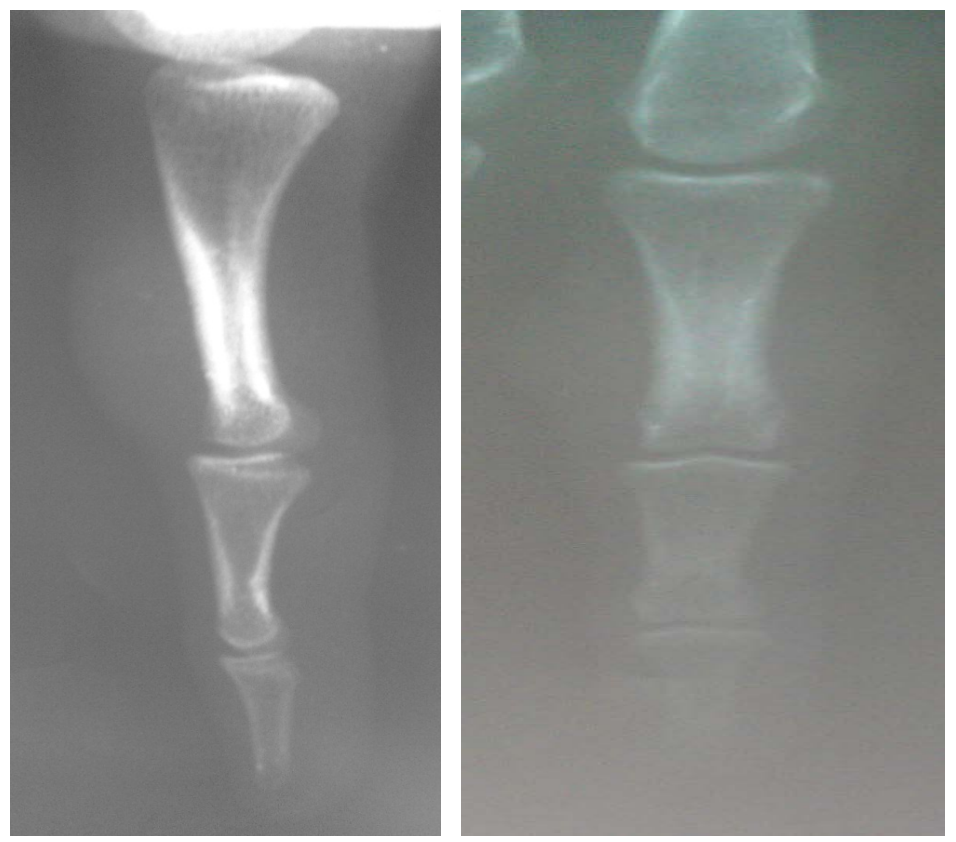

Figure 2. Radiography of index. 


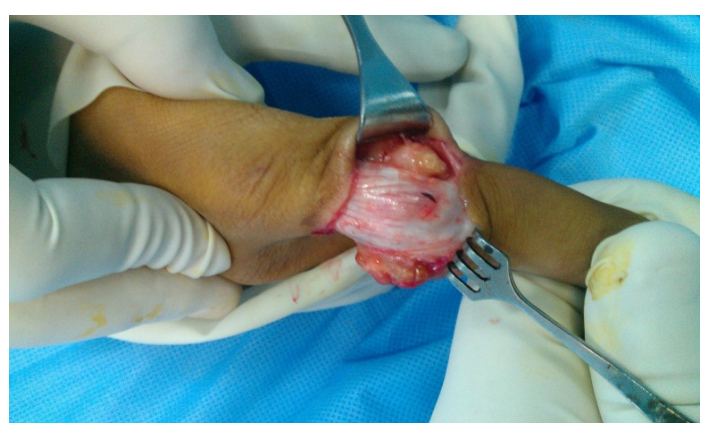

(a)

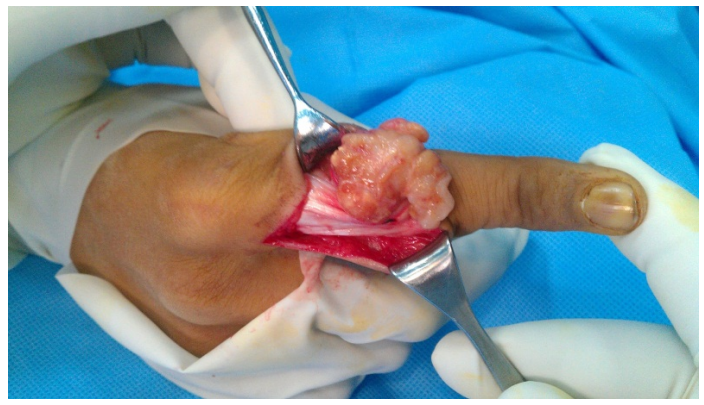

(b)

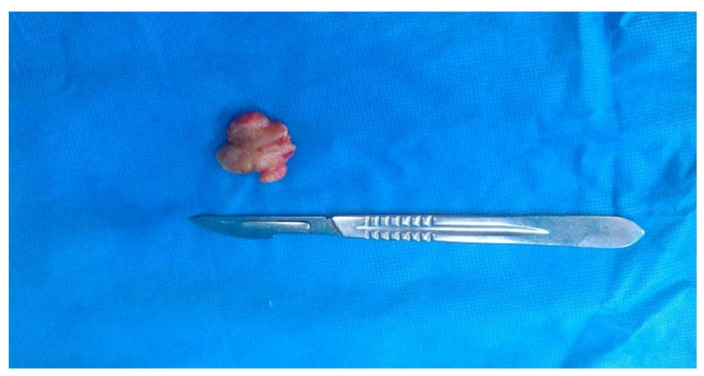

(c)

Figure 3. (a) (b) Intraoperative tumor; (c) Resected specimen.

\section{Discussion}

The giant cells tenosynovial tumor or localized hemopigmented villonodular synovitis [1] affects all tendon synovial preferably at hand. It is a tumor of younger between 30 50 years old, of unknown etiology, sitting mostly on flexors' sheaths. The index is the most frequently touched and its location is the most frequent on distal interphalangeal, then on metacarpal phalangeal and on proximal interphalangeal [2] [3]. In that case, it concerned the proximal interphalangeal of dorsum index at the expense of extensor's sheath.

Clinically, it is an isolated mass, firm, painless, movably under the skin, polylobate. A this stage, the differential diagnosis arises with foreign body granulomas of the hand, tendon sheaths of fibroids, the mucoid cysts, the rheumatoid nodular, the lipoma or the infection [4].

The standard radiology can showed an opacity of soft tissues, often a periosteal reaction, bone erosion or osteoarthritis [5]. In our case, a slight thickening of the cortex 
next to the tumor was noted. On the ultrasound, it is a hypoechoic, homogeneous mass, adjacent to the tendon. The MRI shows hypointensity on T1 and hyperintensity on T2. [6]. Our patient could not benefit from those two diagnosis tests.

The surgery is the only therapeutic mean and consists in total resection of the tumor. Surgical difficulties are related to tumor volume, the local extension to noble elements: tendon and pedicle. In our patient, there was no invasion of noble elements.

The evolution is dominated by relapses [7]. After two years falling, no recurrence nor other complication was noticed.

\section{Conclusion}

The giant cells' tenosynovial tumor of hand is benign tumor of soft tissues, at local malignancy. They are frequent. For the surgical resection, only treatment is sometimes difficult. The prognosis related to recidivism is frequent.

\section{References}

[1] Jones, F.E., Soule, E.H. and Coventry, M.B. (1969) Fibrous Xanthoma of Synovium (Giant Cell Tumor of Tendon Sheath, Pigment Nodular Synovitis). A Study of One Hundred and Einghteen Case. The Journal of Bone \& Joint Surgery, 51, 76-86.

[2] Le Goff, P., Saraux, A. and Guillodo, Y. Affections des gaines synoviales. EMC 15153-A-10.

[3] Messoudi, A., Fnini, S., Labsaili, N., Ghrib, S., Rafai, M. and Largab, A. (2007) Les tumeurs à cellules géantes des gaines synoviales de la main: A propos de 32 cas. Chirurgie de la main, 26, 165-169. http://dx.doi.org/10.1016/j.main.2007.03.008

[4] Bowel, F., Faure, P., Balolet, P., Lamendi, L., Blotman, F. and Claustre, J. (1990) Tumeurs à cellules géantes des gaines synoviales du pied. Médecine et Chirurgie du Pied, 6, 72-78.

[5] Karazick, D. and Karazick, S. (1992) Giant Cell Tumorsof Tendon Sheath: Spectrum of Radiologic Finding. Skeletal Radiology, 21, 219-224.

[6] Midletton, W.D., Patel, V., Teefey, S.A. and Boyer, M.I. (2004) Giant Cell Tumor of the Tendon Sheath: Analysis of Scanographic Finding. American Journal of Roentgenology, 183, 337-339. http://dx.doi.org/10.2214/ajr.183.2.1830337

[7] Lorea, P., Medina, J., Navaro, R. and Foucher, G. (2001) Récidive des tumeurs à cellules géantes des gaines tendineuses après exérèse par une voie d'abord dite des "Dents de la mer"à propos de 25 cas. Annales de Chirurgie Plastique Esthétique, 46, 607-610.

http://dx.doi.org/10.1016/S0294-1260(01)00067-X 
Submit or recommend next manuscript to OALib Journal and we will provide best service for you:

- Publication frequency: Monthly

- 9 subject areas of science, technology and medicine

- Fair and rigorous peer-review system

- Fast publication process

- Article promotion in various social networking sites (LinkedIn, Facebook, Twitter, etc.)

- Maximum dissemination of your research work

Submit Your Paper Online: Click Here to Submit

Or Contact service@oalib.com 